\title{
Teaching NeuroImages: Convexal subarachnoid hemorrhage accompanied by transient global amnesia
}

Markus Beitzke, MD, Christian Enzinger, MD, and Franz Fazekas, MD

Neurology ${ }^{\circledR}$ 2018;90:e1933-e1934. doi:10.1212/WNL.0000000000005567
Correspondence

Dr. Beitzke

markus.beitzke@

klinikum-graz.at

Figure Brain CT and MRI

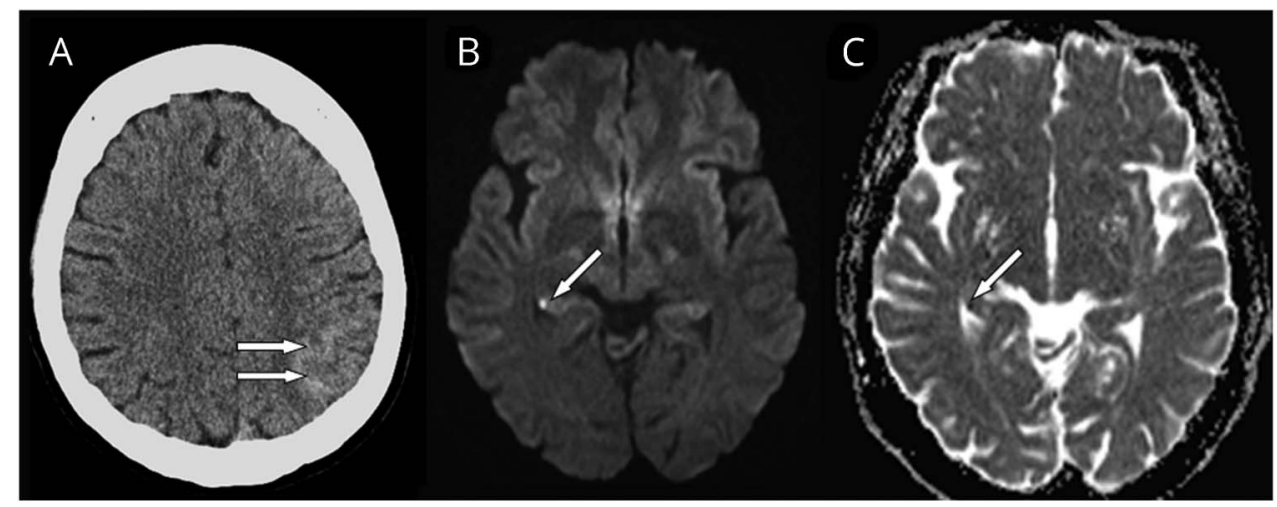

Brain CT showed a hyperdense signal in several sulci of the left frontal lobe consistent with convexal subarachnoid hemorrhage (arrows) (A). MRI revealed a small bright diffusionweighted imaging-positive lesion (arrow) in the right hippocampus (B). Corresponding apparent diffusion coefficient map shows decreased diffusivity (arrow) (C).
A 55-year-old otherwise healthy woman presented with sudden-onset anterograde amnesia, temporal disorientation, and repetitive questioning, which was associated with moderate intensity headache. Consistent with transient global amnesia (TGA), this clinical symptomatology lasted for 8 hours. Brain imaging showed a convexal subarachnoid hemorrhage ${ }^{1}$ (cSAH) (figure, A) and-characteristic of $\mathrm{TGA}^{2}$ - a punctuate diffusion-weighted imaging positive lesion in the right hippocampus on MRI (figure, B and C). Cerebral microbleeds or cortical superficial siderosis were not evident on acute MRI.

The clinical manifestations of cSAH are diverse, including transient focal neurologic episodes, while headache is frequently absent. ${ }^{1}$ After TGA, punctuate hippocampal diffusion-weighted imaging-positive lesions appear in up to $80 \%$ of patients. ${ }^{2}$ The present observation suggests that cSAH may trigger a TGA, while a random coincidence appears unlikely.

\section{Author contributions}

M.B. took care of the patient. All authors interpreted imaging findings and wrote the report.

\section{MORE ONLINE}

$\rightarrow$ Teaching slides links.lww.com/WNL/ A479 


\section{Study funding}

No targeted funding reported.

\section{Disclosure}

The authors report no disclosures relevant to the manuscript. Go to Neurology.org/N for full disclosures.

\section{References}

1. Beitzke M, Gattringer T, Enzinger C, Wagner G, Niederkorn K, Fazekas F. Clinical presentation, etiology, and long-term prognosis in patients with nontraumatic convexal subarachnoid hemorrhage. Stroke 2011;42: 3055-3060.

2. Förster A, Griebe M, Gass A, Kern R, Hennerici MG, Szabo K. Diffusion-weighted imaging for the differential diagnosis of disorders affecting the hippocampus. Cerebrovasc Dis 2012;33:104-115. 


\section{Neurology}

\section{Teaching NeuroImages: Convexal subarachnoid hemorrhage accompanied by transient global amnesia \\ Markus Beitzke, Christian Enzinger and Franz Fazekas \\ Neurology 2018;90;e1933-e1934 \\ DOI 10.1212/WNL.0000000000005567}

This information is current as of May 21, 2018

\section{Updated Information \& Services}

References

Subspecialty Collections

Permissions \& Licensing

Reprints including high resolution figures, can be found at: http://n.neurology.org/content/90/21/e1933.full

This article cites 2 articles, 1 of which you can access for free at: http://n.neurology.org/content/90/21/e1933.full\#ref-list-1

This article, along with others on similar topics, appears in the following collection(s):

All Clinical Neurology

http://n.neurology.org/cgi/collection/all_clinical_neurology MRI

http://n.neurology.org/cgi/collection/mri

Subarachnoid hemorrhage

http://n.neurology.org/cgi/collection/subarachnoid_hemorrhage

Information about reproducing this article in parts (figures,tables) or in its entirety can be found online at:

http://www.neurology.org/about/about_the_journal\#permissions

Information about ordering reprints can be found online:

http://n.neurology.org/subscribers/advertise

Neurology ${ }^{\circledR}$ is the official journal of the American Academy of Neurology. Published continuously since 1951, it is now a weekly with 48 issues per year. Copyright (O) 2018 American Academy of Neurology. All rights reserved. Print ISSN: 0028-3878. Online ISSN: 1526-632X.

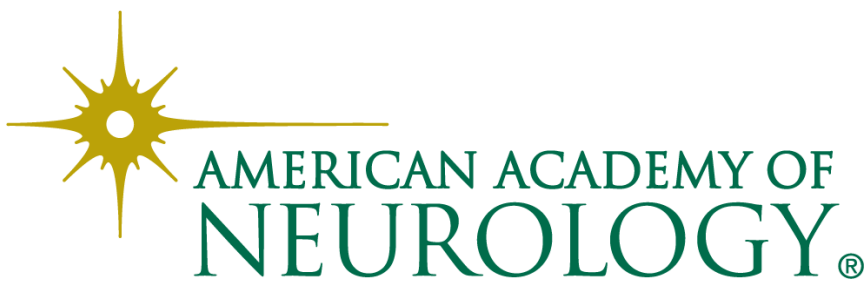

